Journal of Advanced Research in Fluid Mechanics and Thermal Sciences

Journal homepage: www.akademiabaru.com/arfmts.html ISSN: 2289-7879

\title{
Temperature Profile Assessment of Sub-Bituminous Coal Using a Single Burner Combustion Test Facility
}

\author{
Muhamad Shazarizul Haziq Mohd Samsuri ${ }^{1,}{ }^{*}$, Hasril Hasini ${ }^{2}$, Noor Akma Watie Mohd Noor ${ }^{1}$, Meor \\ Mohd Faisal Meor Zulkifli ${ }^{1}$ \\ Fuels \& Combustion Group, Generation \& Environment Unit, TNB Research Sdn. Bhd., 43000 Kajang, Selangor, Malaysia \\ Fluid Dynamics \& Risk Reduction Research Group, Department of Mechanical Engineering, Faculty of Engineering, University Tenaga Nasional, \\ 43000, Kajang, Selangor, Malaysia
}

\section{ARTICLE INFO}

\section{Article history:}

Received 5 February 2020

Received in revised form 25 September 2020

Accepted 2 October 2020

Available online 15 November 2020

\section{ABSTRACT}

This paper presents a thermogravimetric analysis and combustion test for different coals used in one of the coal-fired power plants in Peninsular Malaysia. The main objective is to investigate the suitability of adopting a newly-introduced subbituminuous coal in an existing boiler furnace commonly firing standard design coals. In order to ensure that the new coal will not cause adverse effect to the boiler, detail analytical and thermal performance of the new coal is investigated. The investigation is carried out with standard design and other limiting coals. The combustion test was performed in a scaled down, $150 \mathrm{~kW}$, single swirl burner combustion test facility available in TNB Research Sdn. Bhd. Malaysia. In the study, combustion gas temperature at different sectors downstream of burner region is measured to determine the peak temperature for all tested coals. Based on the investigation, it was noted that coal with the highest fixed carbon content gives the highest temperature measured at all sectors. On the other hand, coal with the lowest fixed carbon gives the lowest temperature. The temperature profile for the newly tested coal was found to be reasonable and comparable to the design and limiting value coals. Even though it was observed that the temperature given by the new coal is the highest slightly downstream of the burner, the temperature was observed to decrease as combustion gas flow further downstream of the combustion test rig. Based on the observation it can be said that the new coal is suitable to be used by the existing boiler furnace.

\section{Keywords:}

Combustion test; Temperature profile; Coal

\section{Introduction}

For the past decades until now, coal has been widely used in the world for various purposes and one of the significant users of coal is power generators. It is known that pollution generated from

\footnotetext{
* Corresponding author.

E-mail address: shazarizulhaziq@gmail.com
}

https://doi.org/10.37934/arfmts.78.1.110 
coal combustion is harmful to human and environment, but it cannot be denied that the world's dependency on coal as the main source for energy is still significant. In recent years, coal quality degradation had caused negative impact to many coal-fired power plants. The current fuel acceptance practice relies on coal certificate of analysis for assessment of newly-introduced coal before firing at power plant, however this practice is insufficient that it does not describe combustion behaviour of the coal sample. In Malaysia, research on coal qualification to achieve the requirements of coal-fired power plant has not been widely explored, hence this offers a gap and opportunity for study of the assessment of newly-introduced coals through analytical and combustion tests.

Among coal-related technologies adopted by many operators to diversify combustion methods is co-firing. Co-firing is an advanced mitigation strategy that could overcome coal degradation issue. It can be broken down into three types namely direct co-firing, indirect co-firing, and gasification-based co-firing [1,2]. Direct co-firing requires mills to crush and pulverize the biomass before being transporting them into the boiler, either separately or combined (blending with coal) [3-5]. The indirect co-firing requires a separate biomass boiler for further steam utilization process [1]. The gasification process, on the other hand has high fuel flexibility due to the combination of the gasification of solid biomass or other fuels and combustion of the fuel gas product in the boiler [6-8]. In addition, torrefaction is another promising co-firing technology in which the biomass volatiles will be decomposed and the remaining final solid product is produced [9-10]. Roni et al., carried out a comprehensive overview of existing biomass co-firing application worldwide and concluded that pollutants emission could be reduced instead of providing a better solution against deforestation [11]. Li et al., also discussed the issue and concluded that increases of biomass constituents would decrease the net emissions of $\mathrm{CO}_{2}$ and $\mathrm{NO}_{x}$ during co-firing process [12]. Among additional benefits of co-firing are low fly ash collected in the hopper and high percentage of burnout particles at furnace outlet as reported by Milicevic et al., [13]. However, this new technology needs further engagements with boiler engineers and operators based on the experiences of the developed countries [13]. Adverse effect such as decreased boiler efficiency is possible due to the presence of high moisture content in the biomass fuel [12]. Therefore, further studies on the drawbacks e.g. ash deposition, corrosion, fly ash utilization, etc. are necessary to prevent any unwanted event during firing [12].

Another promising solution to coal degradation issue is coal-blending. The common strategy is by blending low-grade with higher-grade coals [14]. Studies on this subject were abundant by past researchers using their own blending ingredients. Coal blending can also be a useful tool to reduce the concentration of sulphur, mercury and other pollutants [15-18]. Generally, there are two approaches in determining blend ratio, i.e. computational analysis and analytical fuel tests. Xi et al., used multi-objective decision-making method based on fuzzy mathematics to determine the optimum blending ratio [19]. Adaptive Simulated Annealing Genetic Algorithm (ASAGA) was also used by past researchers to optimize the coal blend properties [20]. In addition to having a powerful optimizing ability, genetic algorithm also provides impressive computing speed [21]. Due to its limitation however, this basic algorithm always produced insufficient information, also known as "premature" outcome [22]. Above all, these methods might not be sufficient to illustrate and describe the complexity of combustion behavior during actual coal firing. As mentioned by Biswas et al., furnaces are designed to use specific fuels, and the substitution of the designed coal as well as the unpredictability of blended coal behaviour have become a great challenge for the plant operation [23]. Prediction of combustion behaviour inside the furnace cannot be made on the basis of these conventional analysis alone. The blended coal composition may resemble the design coal, but the blend behaviour during the combustion may not be the same as expected [24]. The complexity of cofired reaction of different blended coal ranks at the burner zone triggers the need for combustion test to allow real physical coal firing and investigation of combustion behaviour in pilot-scale furnace 
[25]. Thus, the need of combustion test is crucial in the study of the coal blend combustion behaviour in a furnace. This work aims to investigate the viability of a newly introduced coal to be blended with a commonly used coals in an existing power plant boiler. The blend coals were first tested in a pilot scale combustion test rig and the focus of investigation is given towards temperature profiles and the ash deposition produced when the new coal was introduced.

A number of analytical properties could be summarised into one temperature profile which gives an overview of the combustion behaviour. The scaled down combustor might not be similar to the power plant boiler, however the comparison of combustion tests between different coals could be made using the scaled-down combustor. It is important to have consistent combustion parameters such as excess air, coal flow, secondary air temperature and etc. to prevent biasness between the combustion tests. This was proved by Toshiyuki et al., who studied the characterization and behaviour of pulverized coal combustion and highlighted that less excess air leads to oxygen deficiency which in turn, results in increasing of unburned coal while reducing the $\mathrm{NO}_{\mathrm{x}}$ emissions [2630]. However, Debo et al., concluded that an increase in air fuel ratio results in a reduction of $\mathrm{CO}$ formation. The $\mathrm{CO}$ would then react with excess oxygen to produce carbon dioxide. It was also observed that the emission of $\mathrm{NO}_{x}$ pollutant may also increase [31]. Thus, the optimal amount of 10$15 \%$ excess air is required for a common boiler combustion process [32]. These studies also proved that proper controlling sets of parameters were the key factor in enhancing combustion efficiency. To conclude, the temperature assessment of the new coal will be compared with power plant baseline coals through analytical and combustion tests to determine the suitability of the new coal to be applied at power plant.

\section{Methodology}

\subsection{Analytical Test}

\subsubsection{Thermogravimetry analyser (TGA)}

The TGA measures four basic properties of the coal sample namely inherent moisture, volatile matter, fixed carbon and ash content based on sample weight loss for a specific heating program. Other important parameters that could be deduced from the TGA plot are ignition and burnout temperatures, where the former indicates the minimum temperature at which the fuel ignites spontaneously, while the latter indicates the temperature at which the fuel conversion reaches 99 $\%$. This is shown in Figure 1 (Note that a random coal sample is used in the figure for discussion). Note that the blue and red lines indicate mass and rate change of mass respectively. From this figure, the ignition temperature can be determined by identifying the initial point where coal mass starts to drop significantly, consumed due to combustion. In this figure, it is illustrated by the point, $\mathrm{T}_{\text {ignition. }}$ These values are then used to measure the overall combustibility index of the samples using Eq. (1).

Theoretically, the higher the index, the better the combustibility. However, if the 'designed coal' of a specific boiler is to be replaced, a new coal with the closest combustibility index value is always preferred. Maintaining this value would ensure the hotspot region or the flame profile of the new coal to mimic the 'designed coal'. In addition to this, several other factors such as combustion stability, coal particle trajectory trend and etc. have to be assessed as well. Please note that for coalfired boiler applications, coal that has higher combustibility index (as compared to the designed coal) would potentially generate flame hotspots near the burner, while coal with a lower combustibility index would stretch the flame further downstream. The former usually leads to slag build-up at the radiation zone while the latter would increase the risk of secondary flame and related issues. 


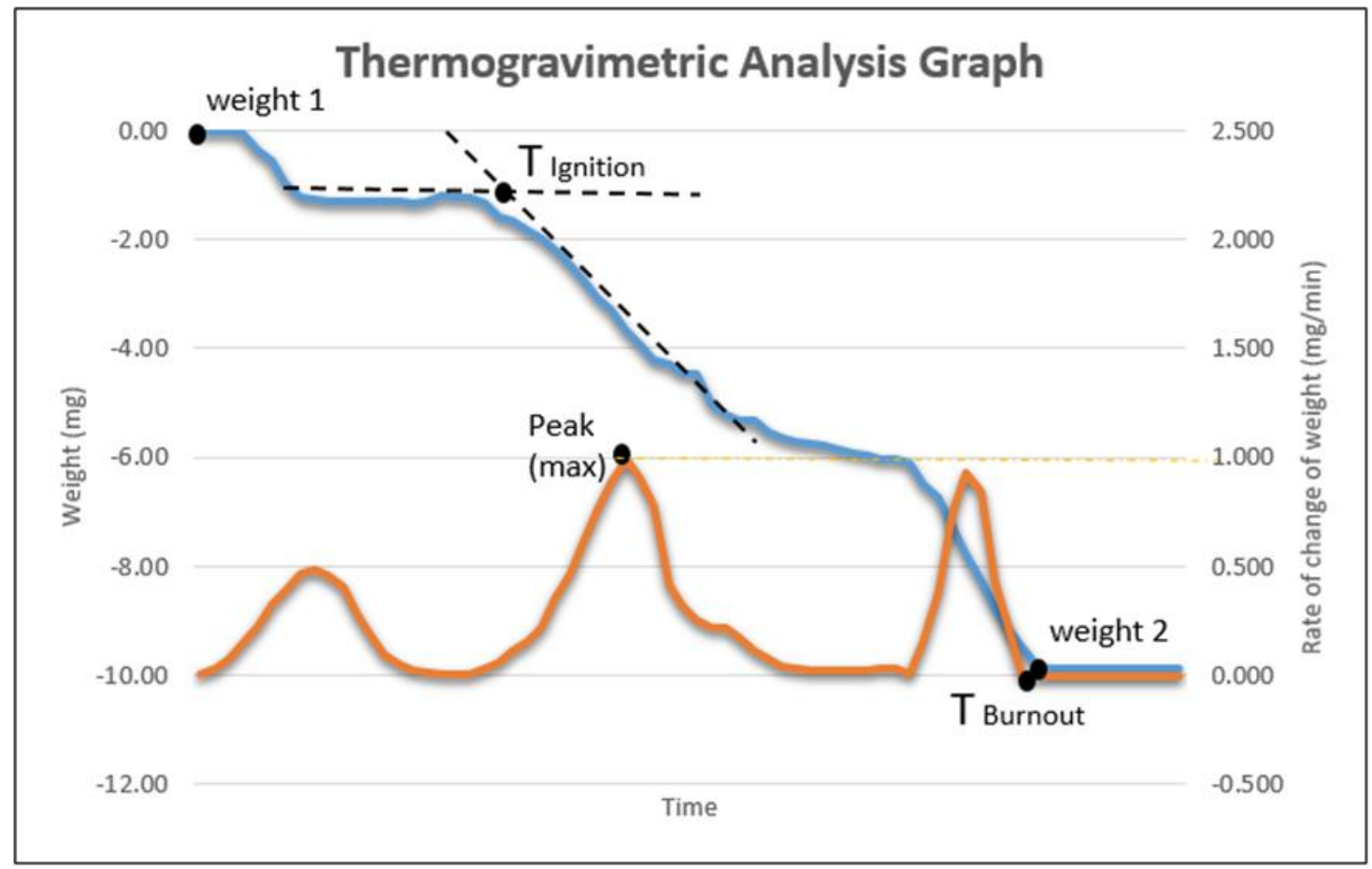

Fig. 1. Thermogravimetric data analysis (the blue and orange lines indicate the weight and rate of change of weight respectively)

Combustibility Index, Si [33] $=\frac{d W / d t(\max ) \times d W / d t(\operatorname{mean})}{T i^{2} \times T b}$

where

$\frac{d W}{d t}(\max ) \quad=\max$ rate of change of weight $(\mathrm{mg} / \mathrm{min})$

$\frac{d W}{d t}($ mean $)=$ mean rate of change of weight $(\mathrm{mg} / \mathrm{min})$

$\mathrm{Ti} \quad=$ Ignition temperature $\left({ }^{\circ} \mathrm{C}\right)$

$\mathrm{Tb} \quad=$ Burnout temperature $\left({ }^{\circ} \mathrm{C}\right)$

\subsubsection{CHNSO analyser}

The main elemental components of the coal under investigation are determined using a CHNSO analyser. This information is important in determining the stoichiometry ratio of air and fuel, $A F R_{\text {Stoichiometry }}$ to achieve complete combustion using Eq. (2).

AFR $R_{\text {Stoichiometry }}=\frac{\dot{m}_{s, \text { air }}}{\dot{m}_{s, \text { fuel }}}$

The ratio is then used to determine both mass flow rates of air and fuel for the combustion testing. Note that the excess air of $10 \%(E R=1.1)$ is used for all combustion tests reported in this study. The equivalence ratio is then determined using the following definition.

Equivalent Ratio $(\mathrm{ER})=\frac{A F R_{\text {Actual }}}{A F R_{\text {Stoichiometry }}}$ 
To ensure a reasonable comparison between one sample to another, the mass flowrate of coal $\left(\dot{m}_{a, f u e l}\right)$ is fixed at $10 \mathrm{~kg} / \mathrm{hr}$. The air-to-fuel ratio and air mass flowrate are determined using Eq. (4) and Eq. (5) respectively.

$$
\begin{aligned}
& A F R_{\text {Actual }}=\frac{\dot{m}_{a, \text { air }}}{\dot{m}_{a, \text { fuel }}} \\
& \dot{m}_{a, \text { air }}=E R \times A F R_{\text {Stoichiometry }} \times \dot{m}_{a, \text { fuel }}
\end{aligned}
$$

\subsection{Combustion Test}

Figure 2 shows the schematic diagram of the $150 \mathrm{~kW}$ combustion test rig used for the combustion analysis. The combustion test rig is equipped with a single swirl burner that has a fuel feed capacity of $10-40 \mathrm{~kg} /$ hour, slagging and fouling probes, K-type thermocouples at combustor sections as well as a flue gas analyser. The combustor main sections consist of the air and fuel inlet, main combustion section, heat exchanger and cyclone. The rig is also equipped with high temperature glass window to allow observation on the flame profile and measurement of heat and temperature using thermal camera. The facility is capable of carrying out complete combustion tests that enable temperature profiles/ flame structure, ash deposition formation and flue gas emission analyses to be measured. The combustor is arranged in an L-shape configuration to mimic a real boiler configuration, whereby the radiation (high temperature furnace/ flame zone) and convection zones could be differentiated. In addition, both radiation and convection zones are equipped with slagging and fouling probes to collect the deposited ash at the probe surface once combustor temperature is cooled below $50{ }^{\circ} \mathrm{C}$ after the combustion test is completed.

Primary air is used as a medium to transport the solid fuel sample while the secondary air acts as an oxidising agent for the combustion process. Based on this analysis, prediction of flame behaviour such as combustion delay can be determined and the thermal properties from thermogravimetric analysis can be justified.

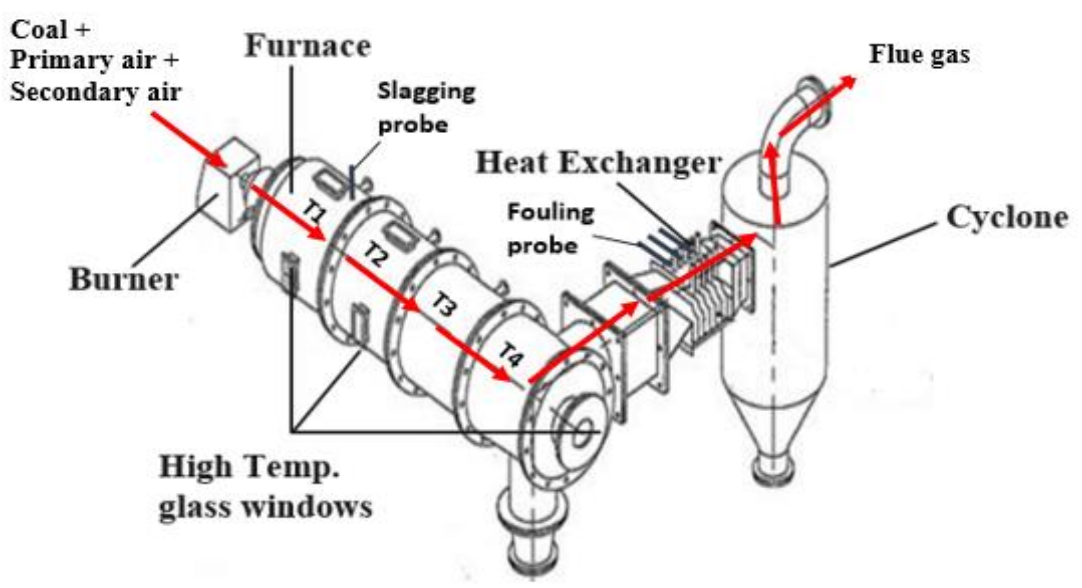

Fig. 2. Schematic diagram of a combustion test rig [34]

To ensure the combustion testing results are meaningful and comparable, the swirl burner angle, fuel feed rate and air to fuel ratio (A/F) for each test were maintained at $7.5^{\circ}, 10 \mathrm{~kg} / \mathrm{hr}$ and $10 \%$ excess air respectively. Details of the combustion test parameters for this work is shown in Table 1. 
Table 1

Parameters for combustion test

\begin{tabular}{lllll}
\hline Parameters & Coal X & Coal A & Coal B & Coal C \\
\hline $\begin{array}{l}\text { Fuel } \\
\text { Flowrate }(\mathrm{kg} / \mathrm{hr})\end{array}$ & 10 & 10 & 10 & 10 \\
\hline $\begin{array}{l}\text { Swirl Burner } \\
\text { Swirl Angle }\left({ }^{\circ}\right)\end{array}$ & 7.5 & 7.5 & 7.5 & 7.5 \\
\hline Primary Air & & & & \\
Temperature $\left({ }^{\circ} \mathrm{C}\right)$ & 27 & 27 & 27 & 27 \\
Flowrate $\left(\mathrm{m}^{3} / \mathrm{hr}\right)$ & 5.5 & 5.5 & 5.5 & 5.5 \\
\hline Secondary Air & & & & \\
Temperature $\left({ }^{\circ} \mathrm{C}\right)$ & 250 & 250 & 250 & 250 \\
Flowrate $\left(\mathrm{m}^{3} / \mathrm{hr}\right)$ & 82.2 & 77.8 & 95.3 & 77.0 \\
\hline Air to fuel ratio & & & & \\
Equivalent Ratio & 1.1 & 1.1 & 1.1 & 1.1 \\
\hline
\end{tabular}

\subsection{Coal Samples}

In this study, coal gravimetric analysis and combustion test is carried out on 4 different coal types, namely Coal A, Coal B, Coal C and Coal X. The power plant boiler has a $700 \mathrm{MW}$ capacity, adopting tangential-firing system. It is designed to fire specific range of coals. During operation, Coal $A$ is preferred due to its impressive combustion performance. Coal B is less preferable due to extremely high combustion gas temperature and high ash deposition. On the other hand, Coal C produces low combustion gas temperature that will lead to high coal consumption for similar output. In this work, Coal A is used as a designed coal while Coal B and Coal C (used as limiting values) are considered as the bad coals due to extreme high and low temperature generated at power plant. Coal $\mathrm{X}$ is a newly introduced, sub-bituminuous coal, yet to be fired in the same power plant boiler furnace. However, due to the unknown effect and boiler response to this coal, detail analysis and combustion test needs to be carried out to ensure that it does not have a negative implication to the existing boiler.

The results of analytical tests (i.e. proximate and ultimate analyses) are used to prepare and illustrate the combustion behaviour of four different coal samples, while the temperature profiles obtained from the combustion tests are used to further analyse the actual combustion behaviour of the samples. The global stoichiometry of each fuel and the amount of air needed in terms of volume flow rate is calculated using the ultimate analysis (as-determined) as presented in Table 2. The secondary air flow rate for each coal are different to maintain approximately 15-20\% excess air in all coal combustion cases.

\section{Results and Discussions}

\subsection{Analytical Test Results}

Results from the analytical tests are tabulated in Table 2 Comparing between different coals, it was noted that the most of the properties are in closed range except for a few significant differences for some parameters. Based on the results obtained, Coal $X$ is expected to give combustion delay due to its lower volatile matter and higher ignition temperature as compared to Coal A. Besides, higher fixed carbon is found for Coal $X$ as compared to the designed coal i.e. Coal $A$ indicates a higher energy released and higher temperature generated during combustion process. However, these assumptions are insufficient without supporting information, hence combustion test analysis is required to justify the assumptions mentioned. Ash content for Coal $\mathrm{X}$ is higher than the designed coal which could lead to a higher ash deposition propensity. In addition, high ash content could also 
lead to a low flame temperature generated during firing due to low combustible elements. Study of the flame profile resulting from this coal was beyond the scope of this paper. Please note that all the analytical tests are conducted repetitively to obtain a reliable and consistent data.

Table 2

Analytical test results

\begin{tabular}{|c|c|c|c|c|c|c|}
\hline \multirow{2}{*}{\multicolumn{3}{|c|}{$\begin{array}{l}\text { Properties } \\
\text { (Air dried basis) }\end{array}$}} & \multicolumn{4}{|c|}{ Sample Type } \\
\hline & & & $\mathrm{X}$ & A & $\mathrm{B}$ & $\mathrm{C}$ \\
\hline \multirow{7}{*}{ 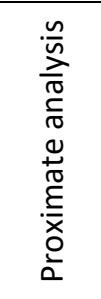 } & Moisture (Inherent) & $\%$ & 9.63 & 13.30 & 6.55 & 13.45 \\
\hline & Volatile Matter & $\%$ & 39.41 & 43.80 & 40.98 & 42.30 \\
\hline & Fixed Carbon & $\%$ & 44.14 & 41.25 & 45.32 & 40.50 \\
\hline & Ash Content & $\%$ & 6.83 & 1.65 & 7.16 & 3.75 \\
\hline & Tignition & ${ }^{\circ} \mathrm{C}$ & 379.33 & 343.10 & 384.80 & 340.10 \\
\hline & Tburnout & ${ }^{\circ} \mathrm{C}$ & 938.93 & 938.80 & 940.05 & 939.70 \\
\hline & Combustibility index, Si $\left(10^{-9}\right)$ & ${ }^{\circ} \mathrm{C}$ & 1.63 & 1.69 & 1.70 & 1.55 \\
\hline \multirow{5}{*}{ 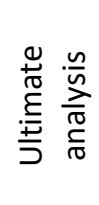 } & Carbon ( C) & $\%$ & 63.00 & 61.80 & 73.45 & 60.80 \\
\hline & Hydrogen ( H ) & $\%$ & 6.00 & 5.63 & 5.76 & 5.62 \\
\hline & Nitrogen ( N ) & $\%$ & 1.74 & 1.09 & 1.46 & 0.95 \\
\hline & Oxygen ( O ) & $\%$ & 11.97 & 16.26 & 5.10 & 15.31 \\
\hline & Sulphur ( S ) & $\%$ & 0.83 & 0.27 & 0.53 & 0.11 \\
\hline
\end{tabular}

\subsection{Temperature Profiles and Flame Behaviour of Different Coals}

Comparison of temperature measurement at four different combustor sections (refer Figure 2) for different coal samples are shown in Figure 3. All coals under test show almost the same temperature profiles as temperature is measured from sector 1 just downstream of the burner to sector 4 , just before the $90^{\circ}$ turns towards the heat exchanger. Coal $B$ gives the highest temperature consistently throughout the sectors except for sector 1 (due to higher secondary air flowrate which indicates the flame hotspot for Coal B is located further downstream inside the combustor as compared to Coal $\mathrm{X}$ ) and this could be attributes to the fact that this coal possesses the highest fixed carbon as compared to other coal samples. On the other hand, Coal $\mathrm{C}$ was found to give the lowest temperature throughout combustor sectors due to its lowest fixed carbon content. In addition, the inherent moisture for this coal is the highest and this could also yield lowest temperature as energy produced were given up to overcome the enthalpy of vaporization of the moisture. A low temperature at sector 4 for all coals indicate that most of the combustible elements within the coal particle are consumed at the upstream sections.

When a new coal (Coal $\mathrm{X}$ ) is introduced to be used together with other design coal, it was found that the thermal performance is comparable. It was noted, however that the temperature recorded at sector 1 for Coal $X$ is the highest. Also, the temperature profile is also found to be consistent as combustion gas travels downstream towards the combustor exit. This behaviour is also in comparison to other design coals. Higher temperature generated by Coal $X$ at sector 1 was found not to be an issue as the value decreases downstream of the flow. The high temperature recorded closed to burner region demonstrates one of its thermal properties, i.e. higher ignition temperature and this does not affect the flame structure in terms of combustion delay and stability near the burner proximity. The surrounding temperature near the burner is high enough to 'self-ignite' Coal X. A low temperature region at sector 4 for all coals indicates that most combustible elements within the coal particle are consumed at the burner upstream sections. Please note that the combustion test is conducted once for each coal types due to the cost of experiment, however the combustion test results are proven to be reliable after validation with the analytical test results. Based on these 
observations, it can be said that Coal $\mathrm{X}$ is a viable alternative coal to be used in an existing power plant boiler furnace.

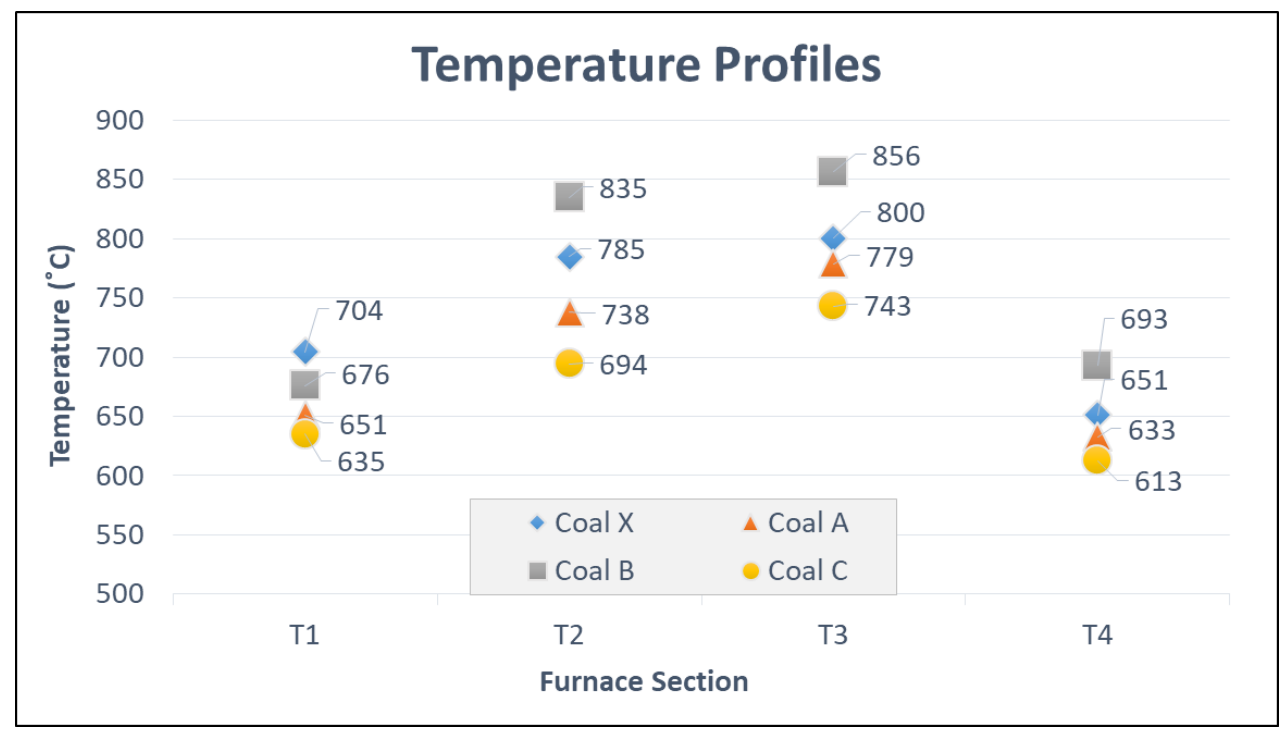

Fig. 3. Comparison of temperature profiles for different coal samples

\section{Conclusions}

Thermogravimetric analysis and combustion test of four different coals have been performed with the objective to determine suitability of a newly introduced coal to be fired in an existing boiler furnace firing only manufacturer's recommended coals. The combustion test was carried out in a scaled down combustor test facility available at TNB Research Sdn. Bhd. Based on the investigation, the following conclusions can be withdrawn.

i. Analytical test result shows comparable properties of the new coal (Coal $X$ ) as compared to other design coals (Coals A, B and C), except for the percentage of volatile matter, which was the lowest for this coal.

ii. The higher ash content of Coal $\mathrm{X}$ indicates a lower number of combustible elements as compared to the designed coal. Besides, the ash deposition propensity is expected to be high.

iii. The general temperature profiles for all tested coals show an identical profile with maximum temperature recorded at Sector 3 and minimum at Sector 4.

iv. Design Coal $B$ gives the highest temperature in all sectors measured (due to the highest fixed carbon content) except for Sector 1 due to the shifted flame hotspot location towards the burner downstream region.

v. Design Coal $\mathrm{C}$ gives the lowest temperature in all sectors measured due to its lowest fixed carbon content. In addition, the low temperature can also be attributed to the highest amount of inherent moisture possessed by this coal. Heat released is expected to be used to overcome the enthalpy of evaporation of the moisture.

vi. Combustion performance of Coal $\mathrm{X}$ is also found to be comparable to other design coals even though it was noted that it gives higher peak temperature just downstream of the burner region. Further downstream, the temperature was reduced and within the range of other design coal temperature, thus it can be said Coal $\mathrm{X}$ is safe to be fired in the boiler. 
Temperature assessment of the new coal has been successfully performed. However, further works need to be executed e.g. analyses of ash deposition propensity and flue gas emissions in order to have a much reliable assessment output of a new coal.

\section{Acknowledgement}

This research was funded by a service project from Fuels \& Combustion Group, TNB Research Sdn. Bhd. The second author would also like to acknowledge the financial support received from the Ministry of Education Malaysia under the FRGS scheme (20180110FRGS). The financial assistance from UNITEN BOLD Talent Scholarship programme is also acknowledged.

\section{References}

[1] Basu, Prabir, James Butler, and Mathias A. Leon. "Biomass co-firing options on the emission reduction and electricity generation costs in coal-fired power plants." Renewable energy 36, no. 1 (2011): $282-288$. https://doi.org/10.1016/j.renene.2010.06.039

[2] Al-Mansour, Fouad, and Jaroslaw Zuwala. "An evaluation of biomass co-firing in Europe." Biomass and bioenergy 34, no. 5 (2010): 620-629. https://doi.org/10.1016/j.biombioe.2010.01.004

[3] Savolainen, Kati. "Co-firing of biomass in coal-fired utility boilers." Applied Energy 74, no. 3-4 (2003): 369-381. https://doi.org/10.1016/S0306-2619(02)00193-9

[4] Karampinis, E., N. Nikolopoulos, A. Nikolopoulos, P. Grammelis, and E. Kakaras. "Numerical investigation Greek lignite/cardoon co-firing in a tangentially fired furnace." Applied Energy 97 (2012): 514-524. https://doi.org/10.1016/i.apenergy.2011.12.032

[5] Pallarés, Javier, Antonia Gil, Cristóbal Cortés, and Carlos Herce. "Numerical study of co-firing coal and Cynara cardunculus in a 350 MWe utility boiler." Fuel Processing Technology 90, no. 10 (2009): 1207-1213. https://doi.org/10.1016/i.fuproc.2009.05.025

[6] Dong, Changqing, Yongping Yang, Rui Yang, and Junjiao Zhang. "Numerical modeling of the gasification based biomass co-firing in a $600 \mathrm{MW}$ pulverized coal boiler." Applied Energy 87, no. 9 (2010): 2834-2838. https://doi.org/10.1016/i.apenergy.2009.05.033

[7] Kalisz, Sylwester, Marek Pronobis, and David Baxter. "Co-firing of biomass waste-derived syngas in coal power boiler." Energy 33, no. 12 (2008): 1770-1778. https://doi.org/10.1016/i.energy.2008.08.001

[8] Mory, A., and T. Zotter. "EU-demonstration project BIOCOCOMB for biomass gasification and co-combustion of the product-gas in a coal-fired power plant in Austria." Biomass and Bioenergy 15, no. 3 (1998): 239-244. https://doi.org/10.1016/S0961-9534(98)00026-9

[9] Maciejewska, A. K., H. Veringa, J. P. M. Sanders, and S. D. Peteves. Co-firing of biomass with coal: constraints and role of biomass pretreatment. Office for Official Publications of the European Communities, 2006.

[10] Arias Rozada, Borja, Covadonga Pevida García, Javier Fermoso Domínguez, Marta González Plaza, Fernando Rubiera González, and José Juan Pis Martínez. "Influence of torrefaction on the grindability and reactivity of woody biomass." (2008). https://doi.org/10.1016/j.fuproc.2007.09.002

[11] Roni, Mohammad S., Sudipta Chowdhury, Saleh Mamun, Mohammad Marufuzzaman, William Lein, and Samuel Johnson. "Biomass co-firing technology with policies, challenges, and opportunities: A global review." Renewable and Sustainable Energy Reviews 78 (2017): 1089-1101. https://doi.org/10.1016/i.rser.2017.05.023

[12] Li, Jun, Artur Brzdekiewicz, Weihong Yang, and Wlodzimierz Blasiak. "Co-firing based on biomass torrefaction in a pulverized coal boiler with aim of 100\% fuel switching." Applied Energy 99 (2012): 344-354. https://doi.org/10.1016/i.apenergy.2012.05.046

[13] Milićević, Aleksandar, Srdjan Belošević, Nenad Crnomarković, Ivan Tomanović, and Dragan Tucaković. "Mathematical modelling and optimisation of lignite and wheat straw co-combustion in 350 MWe boiler furnace." Applied Energy 260 (2020): 114206. https://doi.org/10.1016/i.apenergy.2019.114206

[14] Central Electricity Authority, Ministry of Power, Government of India, New Delhi. Report of the Group for Studying Range of Blending of Imported Coal with Domestic Coal, April 2012, p. 3. www.cea.nic.in/reports/others/thermal/tetd/blending coal.pdf

[15] Wang, Qunying, Lian Zhang, Atsushi Sato, Yoshihiko Ninomiya, and Toru Yamashita. "Effects of coal blending on the reduction of PM10 during high-temperature combustion 1. Mineral transformations." Fuel 87, no. 13-14 (2008): 2997-3005. https://doi.org/10.1016/j.fuel.2008.04.013

[16] Wang, Q., L. Zhang, A. Sato, Y. Ninomiya, and T. Yamashita. "Reduction of PM10 by combustion of coal blends." In 6th Asia-Pacific conference on combustion program of ASPACCO07, Nagoya, Japan. 2007. 
[17] Wang, Qunying, Lian Zhang, Atsushi Sato, Yoshihiko Ninomiya, and Toru Yamashita. "Effects of coal blending on the reduction of PM10 during high-temperature combustion 2. A coalescence-fragmentation model." Fuel 88, no. 1 (2009): 150-157. https://doi.org/10.1016/j.fuel.2008.07.030

[18] Sloss, Lesley. Legislation, standards and methods for mercury emissions control. IEA Clean Coal Centre, 2012.

[19] Jin, Y. A., J. W. Cheng, Q. Bai, and W. B. Li. "Study on the coal mixing ratio optimization for a power plant." In IOP Conference Series: Materials Science and Engineering, vol. 283, no. 1, p. 012019. IOP Publishing, 2017. https://doi.org/10.1088/1757-899X/283/1/012019

[20] Xi-jin, Guo, Chen Ming, and Wu Jia-wei. "Coal blending optimization of coal preparation production process based on improved GA." Procedia Earth and Planetary Science 1, no. 1 (2009): 654-660. https://doi.org/10.1016/i.proeps.2009.09.103

[21] Zhuang, X. C., Y. H. Lu, and Congxin LI. "Solving Job Shop Scheduling Problem by Genetic Algorithm." Computer Engineering 1 (2006): 193-195.

[22] Hwang, Shun-Fa, and Rong-Song He. "Improving real-parameter genetic algorithm with simulated annealing for engineering problems." Advances in Engineering Software 37, no. $6 \quad$ (2006): $406-418$. https://doi.org/10.1016/j.advengsoft.2005.08.002

[23] Biswas, Subhasis, Nandita Choudhury, P. Sarkar, A. Mukherjee, S. G. Sahu, P. Boral, and A. Choudhury. "Studies on the combustion behaviour of blends of Indian coals by TGA and drop tube furnace." Fuel Processing Technology 87, no. 3 (2006): 191-199. https://doi.org/10.1016/i.fuproc.2005.05.002

[24] Raaj, S. Santhosh, S. Arumugam, M. Muthukrishnan, S. Krishnamoorthy, and N. Anantharaman. "Characterization of coal blends for effective utilization in thermal power plants." Applied Thermal Engineering 102 (2016): 9-16. https://doi.org/10.1016/i.applthermaleng.2016.03.035

[25] Ulloa, C., A. G. Borrego, S. Helle, A. L. Gordon, and X. García. "Char characterization and DTF assays as tools to predict burnout of coal blends in power plants." Fuel 84, no. 2-3 (2005): $247-257$. https://doi.org/10.1016/i.fuel.2004.08.008

[26] Suda, Toshiyuki, Makoto Takafuji, Tetsuya Hirata, Motoki Yoshino, and Junichi Sato. "A study of combustion behavior of pulverized coal in high-temperature air." Proceedings of the combustion Institute 29, no. 1 (2002): 503509. https://doi.org/10.1016/S1540-7489(02)80065-7

[27] Katsuki, Masashi, and Toshiaki Hasegawa. "The science and technology of combustion in highly preheated air." In Symposium (International) on combustion, vol. 27, no. 2, pp. 3135-3146. Elsevier, 1998. https://doi.org/10.1016/S0082-0784(98)80176-8

[28] Flamme M., and Kremmer H. Proceedings of European Conference on Natural Gas Policies and Technologies, Athens, Greece, (1992).

[29] Yuan, Jianwei, and Ichiro Naruse. "Effects of air dilution on highly preheated air combustion in a regenerative furnace." Energy \& fuels 13, no. 1 (1999): 99-104. https://doi.org/10.1021/ef980127y

[30] Baukal Jr, Charles E., ed. Oxygen-enhanced combustion. CRC press, 2013.

[31] Li, Debo, Qiang Lv, Yongxin Feng, Chang'an Wang, Xuan Liu, Kai Chen, Kai Xu, Jun Zhong, and Defu Che. "Effects of coal blending and operating conditions on combustion and NOx emission characteristics in a tangentially-fired utility boiler." Energy Procedia 105 (2017): 4015-4020. https://doi.org/10.1016/j.egypro.2017.03.846

[32] Molina, Alejandro, and Christopher R. Shaddix. "Ignition and devolatilization of pulverized bituminous coal particles during oxygen/carbon dioxide coal combustion." Proceedings of the combustion institute 31, no. 2 (2007): 19051912. https://doi.org/10.1016/i.proci.2006.08.102

[33] Xuexin, Sun. "The Experiment Technology and Method of Boiler Combustion [M]." (2002).

[34] Lim, Mook \& Hassan, Haba \& Ahmad, A. \& Hamid, H. \& Mohd Noor, Norliyana." Development of a Solid Fuel Testing Rig Facility for Research in Coal Combustion Performance." Journal of Mechanical Engineering and Automation. (2015). 